\title{
A controversy reviewed
}

\section{The arguments over the Aswan High Dam on the River Nile continue. Julian Rzóska offers this assessment}

\begin{abstract}
THE controversies which rage about large projects may not be resolvable in the final analysis, but at least in the case of the Aswan High Dam in Egypt they have been far from sterile. Hardly anyone seriously disputes the advantages which the taming of a onceerratic river offers in the form of regular and numerous crops and a constant supply of electrical energy. Equally, for many, some of the disadvantages have been painfully apparent--among them the waterlogging and
\end{abstract}

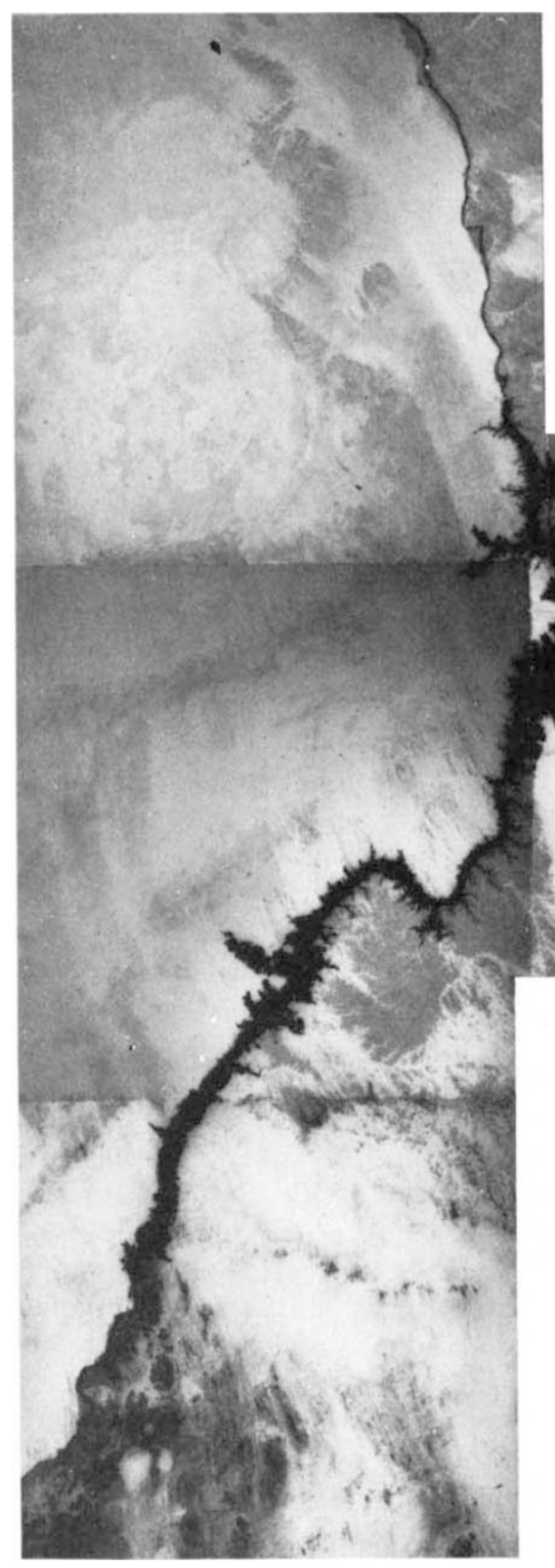

The Aswan High Dam basin from space the picture, taken in 1972, encompasses about $600 \mathrm{~km}$ of the Nile and about $75 \%$ of the drowned area. The basin is now broader. salination of agricultural areas now deprived of fertile silt; the salination threat to fresh water areas in a Nile delta being eroded through a similar lack of silt; and reductions in off-shore fish populations.

The Nile has been under some form of management since Ancient Egyptian times, of course, but it was in the nineteenth and twentieth centuries, when water needs rose sharply with the emergence of the Sudan as a consumer, that the river came to be used intensively. Neither country had much rainfall, and barrages and seasonal storage dams were built; a good deal of the flood surplus had to be discharged into the Mediterranean, however, because of the lack of storage capacity.

But it was the emergence of a multiyear storage dam-the Aswan High Dam - which wreaked the greatest transformation. The main objectives of the dam included the complete use of the available water; the elimination of

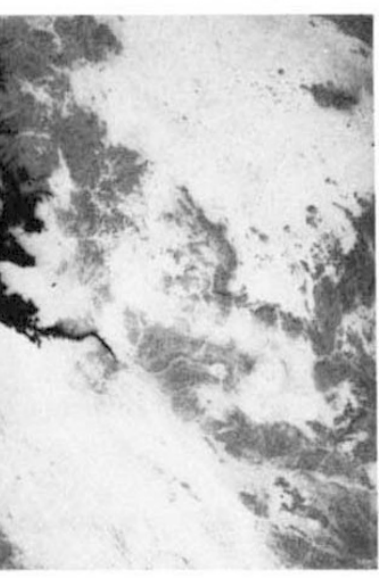

floods; the provision of an even water supply throughout the year; compensation for the Sudan's much larger allocation of water; the creation of a large electrical energy source for the industrial development which could begin to a bsorb Egypt's rapidly rising population.

The construction was almost finished in 1964, and filling proceeded from a level of 120 metres above sea level to 170 metres, which was reached in 1974. The maximum capacity of 183 metres is to be used only at times of exceptionally high floods. The lake created by the dam is $500 \mathrm{~km}$ long, $148 \mathrm{~km}$ of which lie in the Sudan (Lake Nubia). The area of the lake depends on how full it is, but at 180 metres above sea level it would be about $6,000 \mathrm{~km}^{2}$, with a volume of 156,000 million cubic metres. The lake's shape -oblong and relatively narrow with a dendritic outline ---is typical of drowned river valleys; the shore, $9,000 \mathrm{~km}$ long, is bare desert.

It is not such statistics which have attracted attention, however. Indeed, few dam projects have drawn as much criticism as the Aswan High Dam, even before it was built, when the drowning of treasured antiquities was mooted. But with the dam basin now 10 years old, the Egyptians themselves have been taking stock of the main problems created by the dam, most significantly at a symposium in March at the National Research Centre in Cairo which dealt mainly with the effects downstream of the dam.

One of the main criticisms, for example, was that the dam was wasting water it was meant to save. A balance sheet, based on available hydrological documentation, shows the present situation, and is summarised in the table, presented by the chief consultant engineer Lennart Berg of Stockholm. Three important facts emerge: water available for the three areas of irrigated agriculture in Egypt and the Sudan amounts to 79,000 million cubic metres with the dam, as against 60,000 million without it; the big loss by evaporation from the lake is more than offset by the abolition of discharge into the sea; and the dam's buffering capacity allows for storage of the wide fluctuations $(60,000$ to 110,000 million cubic metres) of the Blue Nile floods.

The fate of the famous Nile sediments of the Blue Nile flood, which have built up the alluvial soils of Egypt, has provided the target for further objections. The chief limnologists of the project have thoroughly investigated this for the period up to 1973. Predictably, the sediments fall out where the current slackens and its "carrying capacity" is lost, and this happens in the southern part of the basin; $51 \%$ of the fallout occurs between $410 \mathrm{~km}$ and $345 \mathrm{~km}$ from the dam, and the rest in the next $60 \mathrm{~km}$, almost all of it in the Sudan. Silting up of the lake basin is a long way off, however. Cautious calculations give a figure of about 300 years for the sediments to approach the dam, although this figure is regarded by some as too high. As for the loss of the sediments' fertilising effect on the soils, the delta lakes and the eastern Mediterranean, the detrimental effects are already clear in the grave reduction of the sardine fisheries in the sea and a lesser yield of the delta lakes. The new lake has admittedly created inland fisheries, which in 1973 produced an output of $10,000-13,000$ tons, but the long dis-

Illustrations from J. Rzóska (ed.), The Nile: Biology of an Ancient River, by permission of $\mathrm{Dr} W$. Junk Publishers, The Hague. 


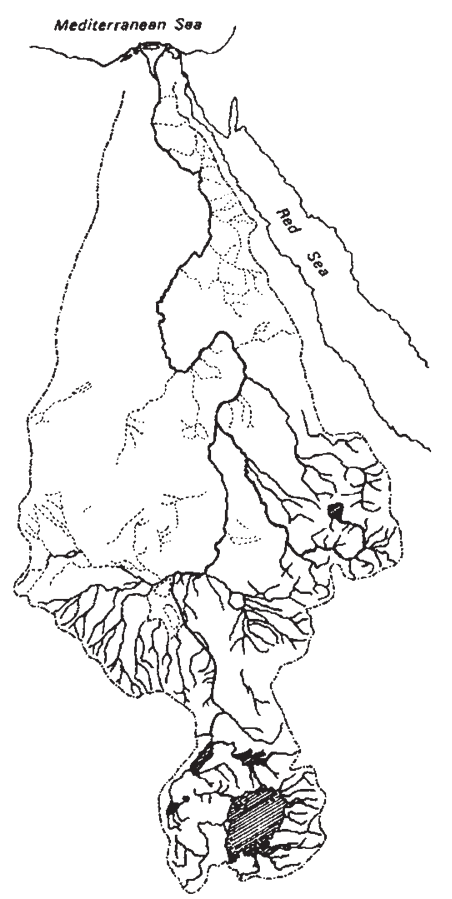

Drainage basin of the Nile system. The dotted lines represent ancient water courses

tances from Aswan make this fish moie expensive than that from the sea and the lakes. The soils themselves will need artificial fertilisers.

Erosion problems have undoubtedly increased with the water head at Aswan now standing some $50 \mathrm{~m}$ above the previous river level and in the absence of the protective layer of sediments. The threats of river bed erosion and to bridges and river banks, all of which have been forecast, are being closely watched, and so far no serious changes have been recorded. Threats to the coast line, which existed before the dam was built, of course, are now more serious, and a team of experts of the "UNESCO-Coastal Project 1973" based in Alexandria is monitoring developments. Another effect of the loss of sediments concerns the northern dam basin itself. Critics predicted that the basin would never fill because of seepage losses into the bare river bed. Careful measurements of the amounts of water needed to fill the basin confirmed a heavy loss, but this is gradually petering out. With a rich phytoplankton already developed, biological sediment will help seal the bottom.

The perrenial irrigation which now prevails raises problems of soil salination which call for more efficient drainage. These problems did not exist with basin irrigation, which was 'ecologically sound', but they are a common phenomenon in most countries relying on irrigation agriculture. The problems are most serious in the delta, which forms $60 \%$ of the cultivated land of Egypt. With a very small slope, arti- ficial drainage by pumping will have to be increased. A change to different methods of irrigation--the sprinkler method used in Israel, for exampleand the introduction of more saltresistant crops have both been suggested, and are practised in many countries with similar irrigation problems.

Other detrimental side effects that were forecast included the spread of water-borne diseases, especially schistosomiasis (bilharzia) and malaria. Bilharzia has been in Egypt for at least 4,000 years; the last serious outbreak of malaria in Egypt occurred in 1942. Because the shores of the new lake are still bare, they do not offer opportunities for snail or insect vectors. But the weed problem has to be watched, particularly the spread of Eichhornia crassipes, which is rampant in the White Nile south of the Gebel Aulia dam about $1,500 \mathrm{~km}$ south of the new lake, and also present in the delta. Eradication of Eichhornia is notoriously difficult and strict monitoring will be a necessity.

The main outcry against the High Dam, however, was that no gains could justify the cultural losses caused by the drowning of a large part of Nubia and its antiquities. The narrow riverain land of Nubia, which stretches from Aswan south to about the cataract IV in the Sudan, contained remains of a series of riverain civilisations from palaeolithic onwards. About one-third of the Nubian Nile valley is now drowned. Following the salvage appeal by UNESCO, intense activity by archaeologists rescued much in a short time; Abu Simbel is only one example, and overshadows equally important results-a large documentation on the prehistory of the region, for example, and the rescue of the remains of the flourishing Christian civilisation at Faras. But much is lost.

Furthermore, the strip of alluvial land surrounded on both sides by the desert was the home of 120,000 Nubians, differing in both origin and language from both Egyptians and Sudanese. They eked out a living through scanty cultivation along the river shores, and some fishing. Many had to seek employment in Egypt and the Sudan. But they always returned to their homeland, and were intensely attached to it. This population, straddling the political boundary between Egypt and Sudan, had to be evacuated in 1964 before the advancing floods; those from the Egyptian part went to Kom Ombo, and those from the Sudan stretch were taken far inland to Khasm el Girba on the Atbara river. This caused much bitterness and serious social consequences.

But if the value of the Aswan High Dam is to be judged, an overall assessment of Egypt's situation is necessary. The population has increased from 10 million in 1900 to 36 million in 1975 . Only about $3 \%$ of the total area of 1 million $\mathrm{km}^{2}$ is cultivated, although a thorough search for more cultivable land has increased the existing $29,000 \mathrm{~km}^{2}$ by one-third. Perennial irrigation has increased by a factor of 1.6 the cropped area (that is, yielding more than one harvest a year). With the increased population the water share per head has actually fallen, and birth control is difficult. And the country lives almost exclusively on agriculture, because its industry is still very small. There are joint projects with the Sudan to search for new water resources--among them a canal bypassing the Upper Nile swamps with huge water losses, a very problematic project affecting the life of the Nilotic tribes of the Sudan. Other projects are under discussion.

The dam has brought Egypt a prospect for the redeployment of some of the population, as has the Roseires Dam in the Sudan. The energy potential of the Aswan High Dam is estimated at 8,000 million $\mathrm{kW}$, which (other things being equal) will allow for some industrial development. The critics of the dam come from climatically and industrially far better-off countries, and must appreciate that Egyptians are aware of the dam's implications; their needs are great, and it is ultimately for them to decide how these should be met. For them, the controversies will presumably end at a time of their own choosing.

Nile Waters during an average year with and without the Aswan High Dam (in million $\mathrm{m}^{3} /$ year)

Water amount available in Sudan Allocation to Sudan

Evaporation losses in new lake

Water passing Aswan

Irrigation of Upper Egypt

Recirculation gains

Water passing Cairo

Irrigation of Delta

Discharged into Mediterranean

\begin{tabular}{cc}
$\begin{array}{r}\text { With } \\
85,000\end{array}$ & $\begin{array}{r}\text { Without } \\
85,000\end{array}$ \\
$-18,500$ & $-13,000$ \\
$-11,000$ & - \\
\hline 55,500 & $-72,000$ \\
$-24,300$ & $-18,800$ \\
$+5,300$ & $+8,000$ \\
\hline 36,500 & $-61,200$ \\
$-36,500$ & $-28,200$ \\
- & $-33,000$ \\
\hline 0 & 0
\end{tabular}

